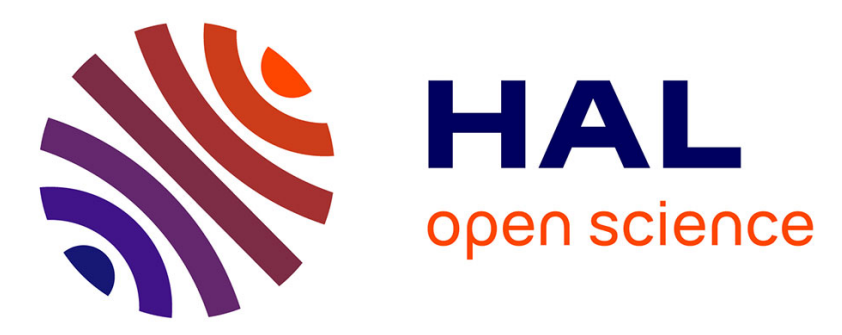

\title{
Preparation of Plastoglobules from Arabidopsis Plastids for Proteomic Analysis and Other Studies
}

Celine Besagni, Lucia Eugeni Piller, Claire Bréhélin

\section{To cite this version:}

Celine Besagni, Lucia Eugeni Piller, Claire Bréhélin. Preparation of Plastoglobules from Arabidopsis Plastids for Proteomic Analysis and Other Studies. Methods in Molecular Biology, 2011, Chloroplast Research in Arabidopsis Methods and Protocols, Volume II, II, pp.223-239. 10.1007/978-1-61779237-3_12. hal-02106325

\section{HAL Id: hal-02106325 \\ https://hal.science/hal-02106325}

Submitted on 5 Nov 2019

HAL is a multi-disciplinary open access archive for the deposit and dissemination of scientific research documents, whether they are published or not. The documents may come from teaching and research institutions in France or abroad, or from public or private research centers.
L'archive ouverte pluridisciplinaire HAL, est destinée au dépôt et à la diffusion de documents scientifiques de niveau recherche, publiés ou non, émanant des établissements d'enseignement et de recherche français ou étrangers, des laboratoires publics ou privés. 
archives-ouvertes

\section{Preparation of Plastoglobules from Arabidopsis Plastids for Proteomic Analysis and Other Studies}

Celine Besagni, Lucia Eugeni Piller, Claire Bréhélin

\section{To cite this version:}

Celine Besagni, Lucia Eugeni Piller, Claire Bréhélin. Preparation of Plastoglobules from Arabidopsis Plastids for Proteomic Analysis and Other Studies. Methods in Molecular Biology, Humana Press/Springer Imprint, 2011, Chloroplast Research in Arabidopsis Methods and Protocols, Volume II, II, pp.223-239. 10.1007/978-1-61779-237-3_12 . hal-02106325

\section{HAL Id: hal-02106325 \\ https://hal.archives-ouvertes.fr/hal-02106325}

Submitted on 5 Nov 2019

HAL is a multi-disciplinary open access archive for the deposit and dissemination of scientific research documents, whether they are published or not. The documents may come from teaching and research institutions in France or abroad, or from public or private research centers.
L'archive ouverte pluridisciplinaire HAL, est destinée au dépôt et à la diffusion de documents scientifiques de niveau recherche, publiés ou non, émanant des établissements d'enseignement et de recherche français ou étrangers, des laboratoires publics ou privés. 


\title{
Preparation of Plastoglobules from Arabidopsis Plastids for Proteomic Analysis and Other Studies*
}

\author{
Celine Besagni, Lucia Eugeni Piller, and Claire Bréhélin
}

\begin{abstract}
Plastoglobules are particles specifically located inside different types of plastids. They mainly contain lipids and proteins and are physically attached to thylakoids. Proteomic studies have underlined the role of plastoglobules in diverse plastid metabolic pathways, such as those producing vitamin $\mathrm{K}$, vitamin $\mathrm{E}$, and carotenoids, and have implicated them in plant response to stress. This chapter describes the isolation of pure and intact plastoglobules from Arabidopsis leaves. The procedure starts with the isolation of intact chloroplasts by centrifugation on a Percoll gradient. Plastoglobules are then separated from the plastid membranes by flotation on a sucrose gradient. Finally, the purity of the plastoglobule fraction is verified by immunoblotting.
\end{abstract}

Key words: Plastoglobules, Sucrose gradient, Chloroplast preparation, Arabidopsis, Immunoblot, Percoll gradient, Flotation, Protein precipitation, Plastid membranes

1. Introduction

Plastoglobules are lipoprotein particles present in different plastid types such as proplastids, chloroplasts, chromoplasts, and gerontoplasts. Plastoglobules are mainly composed of isoprenoids, neutral lipids, and proteins (1). They are physically attached to thylakoids via the outer half of the lipid bilayer of the thylakoid, which surrounds plastoglobules (2). Long viewed as passive lipid droplets, plastoglobules have been receiving increasing attention in the last half decade. Indeed, proteomic studies of plastoglobules $(3,4)$ have demonstrated their active role in plastid biology. This idea is reinforced by the fact that plastoglobule size and number vary depending on plastid type and environmental conditions. Currently, a growing body of evidence suggests that plastoglobules are

*Celine Besagni and Lucia Eugeni Piller have contributed equally to this chapter. 
involved in various metabolic pathways such as those leading to vitamin $\mathrm{K}(5)$, tocopherol $(3,6)$, and carotenoids (4), and in plant response to stress by accumulating antioxidants (e.g., tocopherols) and sequestrating toxic molecules (e.g., fatty acid phytyl esters) (7). In addition, studies of the plastid ultrastructure suggested that plastoglobule size and number are regulated in correlation with the fitness of the thylakoid membranes, putatively playing the role of a reservoir for thylakoid membrane lipids $(1,8)$.

Besides their physiological roles, plastoglobules may present a biotechnological interest for molecular farming by providing a hydrophobic environment necessary for the production of certain proteins, associated with a simple purification procedure (3).

The identification of components (proteins or lipids) specifically localized in plastoglobules relies on preparation of a plastoglobule fraction exempt of any contamination. Such contamination could originate either from light particles present in other compartments of the cell (e.g., oil bodies) or from plastid membranes. Thus, the preparation of pure plastoglobules depends on two critical steps: (1) isolation of intact plastids on Percoll gradients and (2) accurate separation of plastid membranes by flotation on sucrose gradients. The range of sucrose concentrations (5-45\%) that is used for the second step allows the separation of plastoglobules from envelope membranes, which is generally not achieved with standard protocols designed for plastid membrane preparation. In addition, because plastoglobules are physically attached to thylakoids, the procedure must include a step to achieve a good separation of plastoglobules from thylakoids. Finally, the purity of the plastoglobule fraction is verified by immunoblotting, and plastoglobules are then available for proteomic analysis or other studies.

\section{Materials}

\subsection{Arabidopsis Culture}

2.2. Preparation of Intact Chloroplasts and Purification of Plastoglobules
1. Universal soil (Ricoter, Switzerland).

2. Culture trays $(30 \times 50 \mathrm{~cm})$, with propagator lids.

3. Solbac biological control agent (Andermatt Biocontrol, Switzerland); dilute $1 / 400(\mathrm{v} / \mathrm{v})$ in tap water.

4. Phytotron: Percival AR-66L (CLF Plant Climatics GmbH, Germany) or similar, providing the following growth conditions: $8 \mathrm{~h}$ of light per day, $120 \mu \mathrm{mol}$ photons $/ \mathrm{m}^{2} / \mathrm{s}, 20^{\circ} \mathrm{C}$, $60 \%$ humidity.

1. HB buffer: $450 \mathrm{mM}$ sorbitol, $20 \mathrm{mM}$ Tricine- $\mathrm{KOH}, \mathrm{pH} 8.4$, $10 \mathrm{mM}$ ethylenediaminetetraacetic acid (EDTA) (see Note 1), $10 \mathrm{mM} \mathrm{NaHCO}, 1 \mathrm{mM} \mathrm{MnCl}_{2}, 5 \mathrm{mM}$ Na-ascorbate, $0.05 \%(\mathrm{w} / \mathrm{v})$ bovine serum albumin (BSA) fraction $\mathrm{V}$, and $1 \mathrm{mM}$ 
phenylmethylsulfonyl fluoride (PMSF) (see Notes 2 and 3). Prepare freshly (see Note 4).

2. RB buffer $(8 \times)$ stock: $2.4 \mathrm{M}$ sorbitol, $160 \mathrm{mM}$ Tricine- $\mathrm{KOH}$, $\mathrm{pH}$ 7.6, $20 \mathrm{mM}$ EDTA (see Note 1), and $40 \mathrm{mM} \mathrm{MgCl}_{2}$. Working buffer is prepared by diluting $100 \mathrm{~mL}$ of $\mathrm{RB}$ buffer $(8 \times)$ in $700 \mathrm{~mL}$ of water. Store at $-20^{\circ} \mathrm{C}$ (see Note 5 ).

3. $40 \%(\mathrm{v} / \mathrm{v})$ and $85 \%(\mathrm{v} / \mathrm{v})$ Percoll solutions: mix 40 or $85 \mathrm{~mL}$ of Percoll ( $\mathrm{pH}$ 8.5-9.5; Sigma, MO, USA) with $12.5 \mathrm{~mL}$ of RB buffer $(8 \times)$ and adjust volume to $100 \mathrm{~mL}$ with deionized water. These solutions can be kept for several months at $-20^{\circ} \mathrm{C}$.

4. $80 \%(\mathrm{v} / \mathrm{v})$ acetone diluted in water. This can be stored for several weeks at room temperature (see Note 6).

5. TrE buffer: prepare $10 \times$ stock solution with $50 \mathrm{mM}$ Tricine$\mathrm{KOH}, \mathrm{pH} 7.5,2 \mathrm{mM}$ EDTA, and $2 \mathrm{mM}$ dithiothreitol (DTT) (see Note 7$)$. For use, $100 \mathrm{~mL}$ of $\operatorname{TrE}(10 \times)$ is diluted in $900 \mathrm{~mL}$ of water. Buffer can be stored at $-20^{\circ} \mathrm{C}$ for several months.

6. Sucrose $(0.6 \mathrm{M})$ dissolved in $\operatorname{TrE}$ buffer $(1 \times)$. The solution can be stored at $-20^{\circ} \mathrm{C}$ for several months.

7. Protease inhibitor cocktail (e.g., for Plant Cell and Tissue Extracts, Sigma).

8. $45,38,20,15$, and $5 \%(\mathrm{w} / \mathrm{v})$ sucrose solutions: sucrose is dissolved with $\operatorname{TrE}$ buffer $(10 \times)$ and autoclaved deionized water to obtain desired sucrose concentration in $\operatorname{TrE}(1 \times)$. The solutions can be stored at $-20^{\circ} \mathrm{C}$ for several months.

9. Centrifuges: superspeed refrigerated centrifuge (e.g., Sorvall RC-5B, Thermo Scientific, MA, USA), with fixed-angle rotor (e.g., Sorvall SLA1500) and corresponding plastic $250 \mathrm{~mL}$ bottles (Nalgene, NY, USA), or with swinging-bucket rotor (e.g., Sorvall HB-6) and corresponding open polycarbonate $50 \mathrm{~mL}$ tubes (Nalgene); refrigerated bench-top centrifuge (e.g., Eppendorf 5810R), with swinging-bucket rotor (e.g., Eppendorf A4-62) and capped polypropylene $50 \mathrm{~mL}$ tubes (Falcon, BD biosciences, CA, USA); ultracentrifuge (e.g., Beckman L7, Beckman Coulter Inc., CA, USA), with swinging-bucket rotor (e.g., Beckman SW 28) and UltraClear ${ }^{\mathrm{TM}}$ SW28 tubes $(25 \times 89 \mathrm{~mm}$, Beckman $)$.

10. Waring blender homogenizer.

11. Miracloth and cheesecloth.

12. 15- and 50-mL Potter-Elvehjem tissue grinders with Teflon pestles.

13. Spectrophotometer. 


\subsection{Protein Precipitation and SDS- Polyacrylamide Gel Electrophoresis}

1. Sample buffer (SB $4 \times$ ) stock: $200 \mathrm{mM}$ Tris-HCl, $\mathrm{pH} 6.8$, $400 \mathrm{mM}$ DTT, 8\% (w/v) sodium dodecyl sulfate (SDS), $0.4 \%$ $(\mathrm{w} / \mathrm{v})$ bromophenol-blue, and $50 \%(\mathrm{w} / \mathrm{v})$ glycerol. $100 \mu \mathrm{L}$ of SB $(4 \times)$ should be diluted in $300 \mu \mathrm{L}$ of water and then used to resuspend dried proteins.

2. Stock solutions for running gel: $40 \%(\mathrm{w} / \mathrm{v})$ acryl/bisacrylamide $(37.5 / 1) ; 2$ M Tris-HCl, $\mathrm{pH} 8.8 ; 20 \%$ (w/v) SDS; $N, N, N^{\prime}, N^{\prime}$-tetramethylethylenediamine (TEMED); 10\% (w/v) ammonium persulfate (APS) prepared in water and stored frozen in single-use aliquots $(200 \mu \mathrm{L})$ at $-20^{\circ} \mathrm{C}$ (see Note 8$)$.

3. Stock solutions for stacking gel: $40 \%(\mathrm{w} / \mathrm{v})$ acryl/bisacrylamide (37.5/1); 0.5 M Tris-HCl, pH 6.8; 20\% (w/v) SDS; TEMED; and $10 \%(\mathrm{w} / \mathrm{v})$ APS.

4. Running buffer ( $5 \times$ stock solution): $100 \mathrm{mM}$ Tris, $1 \mathrm{M}$ glycine, $\mathrm{pH} 8.3$, and $0.5 \%(\mathrm{w} / \mathrm{v})$ SDS. Store at room temperature. For use, dilute $100 \mathrm{~mL}$ of $5 \times$ stock with $900 \mathrm{~mL}$ of water.

5. SDS-PAGE Molecular Weight Standards, Broad Range (Bio-Rad, CA, USA), or similar.

6. Microcentrifuge.

7. Speed Vacuum Concentrator 5301 (Eppendorf, Germany), or similar.

8. Electrophoresis system for SDS-PAGE (e.g., PerfectBlue Dual Gel System Twin ExWS with glass plates $(20 \times 10 \mathrm{~cm})$, a 20 -teeth comb, and two $0.8-\mathrm{mm}$ spacers; PeqLab Biotechnologies GmbH, Germany).

9. Power supply (e.g., Power Pac 300, Bio-Rad).

2.4. Verification of Plastid Membrane Fractions Purity by Immunoblotting
1. Nitrocellulose membrane (e.g., Protran $\mathrm{R}, 0.45 \mu \mathrm{m}$ pore size, Whatman, UK).

2. Blotting paper (e.g., 3MM, Whatman).

3. Transfer tank (e.g., Trans-Blot TM Cell, Bio-Rad).

4. Rocking platform (e.g., Stuart SSM3 3D gyratory rocker, Bibby Scientific Limited, UK).

5. Transfer buffer: $15 \mathrm{mM} \mathrm{NaH} \mathrm{PO}_{4}, 0.05 \%$ (v/v) SDS, and $20 \%$ (v/v) ethanol. Prepare freshly.

6. AmidoBlack staining solution: $45 \%(\mathrm{v} / \mathrm{v})$ ethanol, $10 \%(\mathrm{v} / \mathrm{v})$ glacial acetic acid, and 0.1\% (w/v) AmidoBlack 10B (Merck, NJ, USA). Store at room temperature (see Note 9 ).

7. Destaining solution: $40 \%(\mathrm{v} / \mathrm{v})$ ethanol, $10 \%(\mathrm{v} / \mathrm{v})$ acetic acid. Store at room temperature.

8. PBS buffer $(10 \times)$ stock: $1.4 \mathrm{M} \mathrm{NaCl}, 27 \mathrm{mM} \mathrm{KCl}, 0.1 \mathrm{M}$ $\mathrm{Na}_{2} \mathrm{HPO}_{4}$, and $20 \mathrm{mM} \mathrm{KH} \mathrm{PO}_{4}$. Dilute $100 \mathrm{~mL}$ with $900 \mathrm{~mL}$ of water to obtain $\mathrm{I} \times \mathrm{PBS}$ for use. 
9. TBS buffer $(10 \times)$ stock: $10 \mathrm{mM}$ Tris- $\mathrm{HCl}, 0.15 \mathrm{M} \mathrm{NaCl}$, $\mathrm{pH}$ 7.5. Dilute $100 \mathrm{~mL}$ with $900 \mathrm{~mL}$ of water to obtain $1 \times$ TBS for use.

10. Blocking buffer: $5 \%(\mathrm{w} / \mathrm{v})$ nonfat dry milk in $1 \times$ PBS or $1 \times$ TBS.

11. Primary antibodies: (1) the anti-AtPGL35 serum (Agrisera, Sweden), specific to plastoglobules, has been raised against the Arabidopsis thaliana plastoglobulin AtPGL35. Use it diluted $1: 3,000$ in PBS with $5 \%(\mathrm{w} / \mathrm{v})$ nonfat dry milk; (2) the antiLHCB2 serum (Agrisera) is a marker of thylakoid membranes and recognizes chlorophyll $\mathrm{a} / \mathrm{b}$-binding proteins of the light harvesting antenna complex II (LHCII). Use it diluted 1:3,000 in PBS, $5 \%(\mathrm{w} / \mathrm{v})$ nonfat dry milk; (3) the anti-Toc75 serum (Agrisera) is specific to the plastid envelope membrane and has been raised against the $75 \mathrm{kDa}$ component of the translocon at the outer envelope membrane of chloroplasts (TOC). Use it diluted 1:3,000 in TBS, 5\% (w/v) nonfat dry milk. Sera should be stored at $-20^{\circ} \mathrm{C}$; however, an aliquot of around $50 \mu \mathrm{L}$ can be kept at $4^{\circ} \mathrm{C}$ for daily use.

12. Secondary antibody: horseradish peroxidase-coupled goat antirabbit IgG (Bio-Rad) diluted $1: 3,000$ in PBS or TBS with $5 \%$ (w/v) nonfat dry milk.

13. Enhanced chemiluminescent (ECL) reagent: $0.1 \mathrm{M}$ Tris- $\mathrm{HCl}$, pH 8.5, $0.2 \mathrm{mM}$ p-coumaric acid (Fluka, Switzerland), $1.25 \mathrm{mM}$ 3-aminophthalhydrazide (Luminol, Fluka) (see Note 10).

14. $3 \%(\mathrm{w} / \mathrm{w}) \mathrm{H}_{2} \mathrm{O}_{2}$ : the $\mathrm{H}_{2} \mathrm{O}_{2}$ stock is diluted in water and the solution is stored at $4^{\circ} \mathrm{C}$ for several weeks.

15. Chemiluminescent detection in a dark room: Hyperfilm ECL $18 \times 24 \mathrm{~cm}$ X-ray film (GE Healthcare, NJ, USA) placed in an $\mathrm{X}$-ray film cassette (e.g., Rego Gollwitzer GmbH, Germany) and developed in a tabletop processor (e.g., SRX-101A, Konica Minolta, Japan). Alternatively, the luminescent signal may be monitored using a luminescence imaging device (e.g., ChemiDock system and the QuantityOne software, both from Bio-Rad).

16. Stripping buffer: $62.5 \mathrm{mM}$ Tris- $\mathrm{HCl}, \mathrm{pH} 6.8,2 \%(\mathrm{w} / \mathrm{v})$ SDS, $100 \mathrm{mM} \beta$-mercaptoethanol (see Note 11).

\section{Methods}

\subsection{Arabidopsis Culture}

1. Sow Arabidopsis thaliana seeds on six trays filled with universal soil (see Note 12). The soil is first watered with Solbac solution to prevent the growth of insect larvae. Trays are covered with transparent plastic propagator lids (or cling film) to ensure appropriate humidity for germination. 


\subsection{Preparation of Intact Chloroplasts and Purification of Plastoglobules}

2. After 2 days at $4^{\circ} \mathrm{C}$, place the trays in a phytotron for $6-8$ weeks. Lids are removed after 2 weeks to avoid algae and/or fungi development.

We describe here the procedure we routinely follow to obtain pure Arabidopsis plastoglobules. Each step of the protocol below should be performed at $4^{\circ} \mathrm{C}$ to preserve the integrity of the chloroplasts, and to avoid protein degradation. When the starting material, and consequently, the amount of isolated chloroplasts, are limiting, smaller sucrose gradients can be prepared in appropriate tubes by proportionally reducing the volume of each sucrose solutions, as exemplified in Vidi et al. (9).

1. Prior to harvesting, place plants in the dark for 24-48 h to avoid starch accumulation (see Note 13).

2. Harvest Arabidopsis leaves with scissors or a scalpel, weigh them in a beaker (see Note 14), and then maintain them in chilled water for $30 \mathrm{~min}$ (see Note 15).

3. Prepare six Percoll gradients as follows. Start by pouring $15 \mathrm{~mL}$ of $40 \%$ Percoll solution into a $50-\mathrm{mL}$ open tube. Then, with a glass Pasteur pipette, carefully introduce $5 \mathrm{~mL}$ of $85 \%$ Percoll solution below the $40 \%$ Percoll layer. Keep the gradients at $4^{\circ} \mathrm{C}$.

4. Using a Waring blender homogenizer, grind the leaves three times in $500 \mathrm{~mL}$ of cold $\mathrm{HB}$ buffer ( $5 \mathrm{~s}$ at high strength and then two times $3 \mathrm{~s}$ at low strength) (see Note 16).

5. Filter the homogenate immediately through two layers of cheesecloth and one layer of Miracloth placed in a funnel on top of an Erlenmeyer flask. Gently squeeze the homogenate inside the cheesecloth to extract most of the liquid.

6. Divide the filtrate between three or four $250-\mathrm{mL}$ bottles and then centrifuge for $10 \mathrm{~min}$ at $1,075 \times g$ in an SLAl500 fixedangle rotor.

7. Gently resuspend each pellet with $1-2 \mathrm{~mL}$ of $1 \times \mathrm{RB}$ buffer (see Note 17) and pool the crude chloroplast extracts in a 50-mL Falcon tube. If necessary, add additional RB buffer to resuspend any residual pellet material, and at the end, rinse the tubes with small amounts of additional RB. Gently mix the suspension by inverting the tube and then load $2-3 \mathrm{~mL}$ of crude chloroplast extract onto each Percoll gradient.

8. Centrifuge the gradients for $10 \mathrm{~min}$ at $13,600 \times g$ in an HB-6 swinging-bucket rotor (see Note 18). At the end of the centrifugation, intact chloroplasts are located at the interface between the 85 and $40 \%$ Percoll phases. The green ring situated in the upper part of the gradient corresponds to broken chloroplasts and should be eliminated. 
9. Aspirate most of the $40 \%$ Percoll layer with a vacuum aspirator, delicately collect the band of intact chloroplasts with a plastic pipette (with large opening), and transfer to a 50-mL Falcon tube.

10. Distribute chloroplasts from all gradients among two $50-\mathrm{mL}$ Falcon tubes and dilute with 10 volumes of RB buffer $(1 \times)$. Gently invert the tube to mix.

11. Centrifuge the suspension $2 \mathrm{~min}$ at $2,600 \times g$ in a swingingbucket rotor (A4-62).

12. Carefully decant the supernatant as the pellet is very loose.

13. Resuspend the pellet in $5 \mathrm{~mL}$ of $\operatorname{TrE}$ buffer $(1 \times)$ and quantify the chlorophyll (see Note 19).

14. Adjust the sample volume to $50 \mathrm{~mL}$ with $\operatorname{TrE}$ buffer $(1 \times)$ to wash the chloroplasts, and then centrifuge for $10 \mathrm{~min}$ at $2,600 \times g$ in a swinging-bucket rotor (A4-62).

15. Carefully decant the supernatant and then resuspend (see Note 20 ) the chloroplast pellet with $0.6 \mathrm{M}$ sucrose/TrE to a concentration of $2-3 \mathrm{mg} / \mathrm{mL}$ of chlorophyll. Add a cocktail of antiproteases to preserve protein integrity.

16. Incubate on ice for $10 \mathrm{~min}$ and then freeze at $-80^{\circ} \mathrm{C}$ for at least $1 \mathrm{~h}$ (see Note 21).

17. Thaw the chloroplast suspension and dilute with 2 volumes of TrE buffer $(1 \times)$.

18. Homogenize chloroplast suspension for at least 20 strokes in a 50-mL Potter homogenizer and then transfer the homogenate into UltraClear SW28 tubes (see Note 22).

19. Carefully balance the tubes and then perform ultracentrifugation at $100,000 \times g$ in a swinging-bucket rotor for $1 \mathrm{~h}$ (see Note 23).

20. Remove the supernatant, which corresponds to the stroma, and resuspend the pellet of total membrane (which contains plastoglobules) into $45 \%$ sucrose/ TrE to reach a concentration of 2-6 $\mathrm{mg}$ of chlorophyll per $\mathrm{mL}$ (typically, $\sim 10-20 \mathrm{~mL}$ $45 \%$ sucrose/TrE solution will be required) (see Notes 24 and 25 ).

21. Homogenize the resuspended membranes by 20 strokes in a 15-mL Potter homogenizer (see Note 26).

22. Pour $5 \mathrm{~mL}$ aliquots of the membranes homogenate into the required number of UltraClear SW28 tubes, and carefully overlay each aliquot with the sucrose/TrE solutions in the following order: $6 \mathrm{~mL}$ of $38 \%$ sucrose, $6 \mathrm{~mL}$ of $20 \%$ sucrose, $4 \mathrm{~mL}$ of $15 \%$ sucrose, and finally $8 \mathrm{~mL}$ of $5 \%$ sucrose to the top of the tube (see Note 27). 


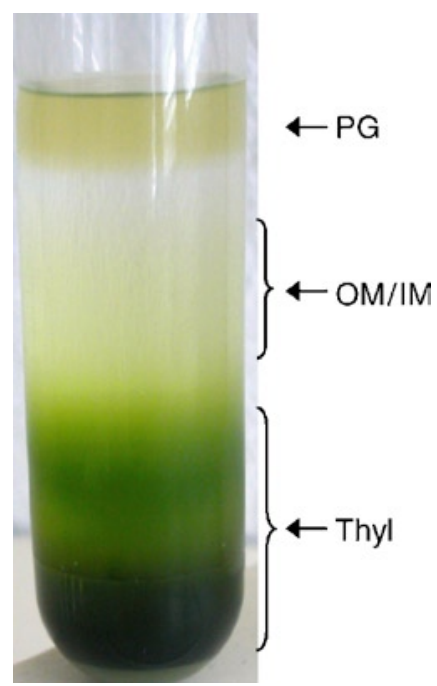

Fig. 1. Separation of total membranes from isolated Arabidopsis chloroplasts by flotation on a discontinuous sucrose gradient. Plastoglobules $(\mathrm{PG})$ are visible as a yellowish layer at the top of the gradient. Outer and inner envelope membranes (OM/IM) are yellow; thylakoid membranes (Thyl) are green.

23. Carefully balance the tubes and ultracentrifuge them overnight at $100,000 \times g($ see Notes 28 and 29). An example of the gradient that is obtained after the overnight centrifugation is given in Fig. 1.

24. For each gradient, collect $1-\mathrm{mL}$ fractions with a micropipette, starting from the top of the gradient (fraction 1) and ending at the bottom (approximately 32 fractions), and store them at $-20^{\circ} \mathrm{C}$. An illustration of the content of plastoglobules, envelopes and thylakoid membrane fractions observed with a confocal microscope is given Fig. 2. Typically, plastoglobules are contained in fractions 1-6, envelopes in fractions 14-18, and thylakoid membrane in fractions 25-32. However, the exact plastid membrane distribution varies from one experiment to another and has to be checked by immunoblotting as described below.

3.3. Protein

Precipitation and SDS-PAGE
Here, we describe the procedure that we routinely follow to verify the plastid membrane distribution among the sucrose gradient fractions, and the purity of the plastoglobule fraction before subsequent analysis. However, the procedure needs to be modified depending on the goal of the experiment. For example, for mass spectrometry (MS) analysis, plastid membranes containing 25-30 mg of chlorophyll are loaded on one sucrose gradient and total proteins contained in $1 \mathrm{~mL}$ of the plastoglobule fraction are precipitated and separated on SDS-PAGE. Diverse staining methods (e.g., colloidal blue or silver staining) can then be used to visualize proteins before MS analysis. 


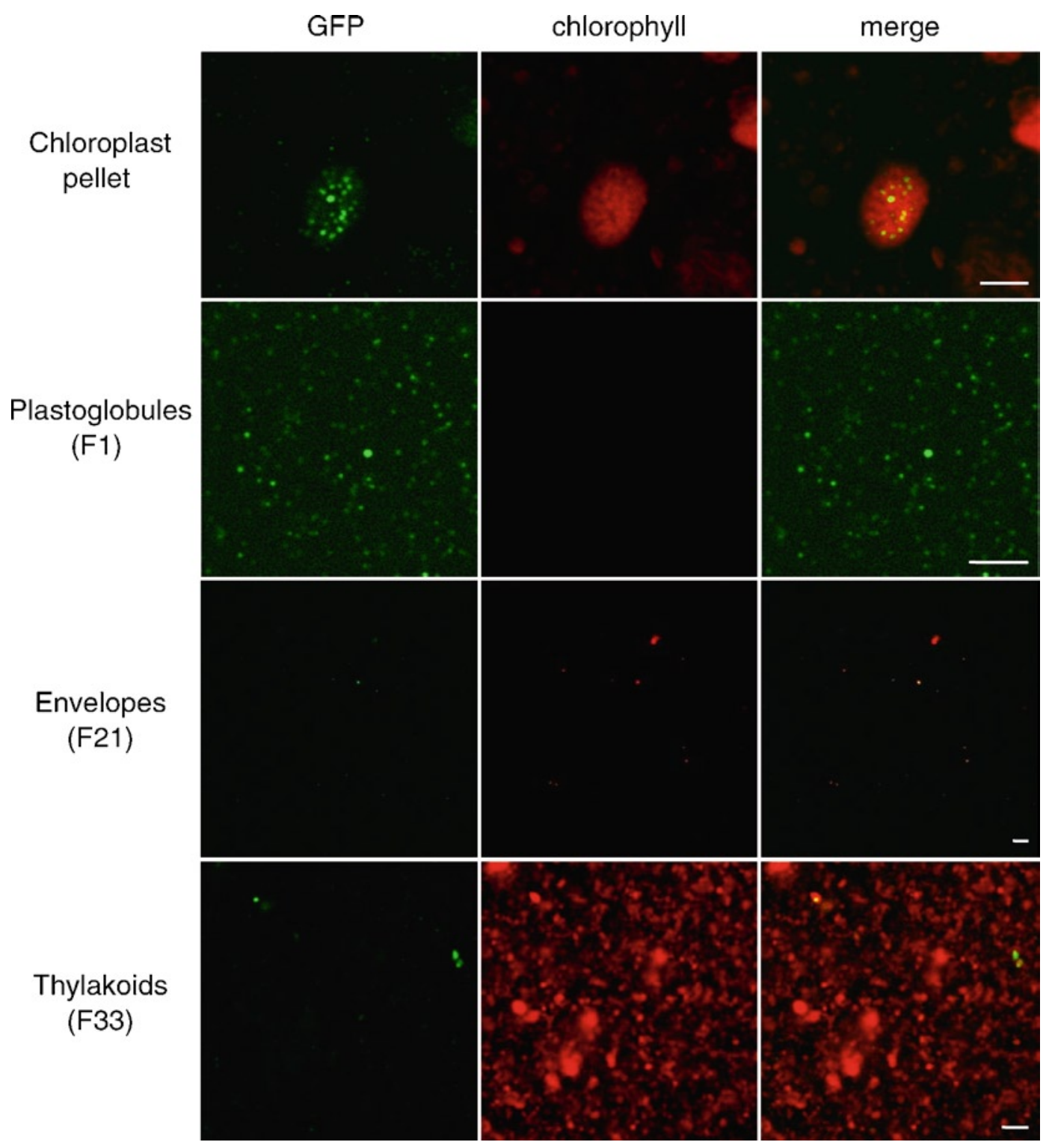

Fig. 2. Observation of the different plastid membrane fractions by confocal microscopy. Chloroplast membranes from Arabidopsis leaves expressing a plastoglobule marker (AtPGL35) fused to the green fluorescent protein (GFP) under the control of the constitutive $35 \mathrm{~S}$ promoter were separated by flotation on a sucrose gradient. Fluorescence of fractions $\mathrm{F} 1$ (plastoglobules), F21 (envelopes), F33 (thylakoids), and of intact chloroplasts (pellet) is visualized by confocal laser scanning microscopy. GFP and chlorophyll autofluorescence were monitored with a Leica TCS SP5 microscope (Leica Microsystems, Germany) using the $488 \mathrm{~nm}$ laser line and detection windows of $490-540$ and $650-800 \mathrm{~nm}$, respectively. Scale bars: $5 \mu \mathrm{m}$.

1. Different volumes of each even (or odd) fraction are transferred to microtubes for protein precipitation: $400 \mu \mathrm{L}$ from each of fractions 1-18 (split between two tubes of $200 \mu \mathrm{L}$ for each fraction), and $200 \mu \mathrm{L}$ of the upper fractions, stroma (St) and intact chloroplasts (see Note 30 ). 
3.3.2. Separation

of Proteins by SDS-PAGE
2. To $200 \mu \mathrm{L}$ of sample, add $160 \mu \mathrm{L}$ of chloroform and $480 \mu \mathrm{L}$ of methanol.

3. Vortex the tubes for $1 \mathrm{~min}$ and then add $640 \mu \mathrm{L}$ of deionized $\mathrm{H}_{2} \mathrm{O}$.

4. Centrifuge the tubes for $1 \mathrm{~min}$ at maximum speed in a microcentrifuge.

5. Remove the upper phase, taking care not to disturb the protein band at the interphase (see Note 31).

6. Add $480 \mu \mathrm{L}$ of methanol to the lower phase and vortex.

7. Centrifuge for $5 \mathrm{~min}$ at maximum speed in a microcentrifuge, remove the supernatant, and dry the protein pellet with a speed vacuum concentrator (around $10 \mathrm{~min}$ at $30^{\circ} \mathrm{C}$ ) (see Note 32 ).

8. Resuspend the proteins in SB buffer: $20 \mu \mathrm{L}$ each for fractions 1-18 (10 $\mu \mathrm{L}$ for each tube of each fraction, which are then pooled together), $15 \mu \mathrm{L}$ each for fractions $19-24,30 \mu \mathrm{L}$ each for fractions 25-28 and stroma, and $60 \mu \mathrm{L}$ for total chloroplasts and for each of the remaining fractions (see Note 33 ).

9. Heat the protein samples for $10 \mathrm{~min}$ at $65^{\circ} \mathrm{C}$. Proteins are now ready to be loaded on an SDS-PAGE gel.

The following steps describe the preparation and the use of a $12 \%$ SDS-PAGE gel using the PerfectBlue Dual Gel Twin ExWS electrophoresis system (PeqLab).

1. Scrupulously clean with deionized water and technical ethanol the glass plates $(20 \times 10 \mathrm{~cm})$ before assembling the electrophoresis system.

2. For one $12 \%$ acrylamide running gel, mix in a $50-\mathrm{mL}$ Falcon tube: $5 \mathrm{~mL}$ of deionized water, $3 \mathrm{~mL}$ of $40 \%$ acryl/bisacrylamide (see Note 34), $2 \mathrm{~mL}$ of $2 \mathrm{M}$ Tris- $\mathrm{HCl}, \mathrm{pH} 8.8$, and $50 \mu \mathrm{L}$ of $20 \%$ SDS. When everything is ready, add $5 \mu \mathrm{L}$ of TEMED and $80 \mu \mathrm{L}$ of $10 \%$ APS (see Note 35 ) to the running gel solution, rapidly mix, and pour the gel leaving a space for the stacking gel (see Note 36). Overlay with isopropanol. The gel should polymerize in less than $30 \mathrm{~min}$ at room temperature.

3 . Remove the isopropanol with absorbing paper and prepare stacking gel by mixing in a $50 \mathrm{~mL}$ Falcon tube: $3.9 \mathrm{~mL}$ of water, $500 \mu \mathrm{L}$ of $40 \%$ acry/bisacrylamide, $600 \mu \mathrm{L}$ of $0.5 \mathrm{M}$ Tris- $\mathrm{HCl}, \mathrm{pH} 6.8$, and $25 \mu \mathrm{L}$ of $20 \%$ of SDS. Finish by adding $5 \mu \mathrm{L}$ of TEMED and $40 \mu \mathrm{L}$ of $10 \%$ APS. Mix and pour the stacking gel on the running gel until reaching the top of the plate and carefully insert the comb. The stacking gel should polymerize within $20 \mathrm{~min}$ at room temperature.

4. Once polymerized, assemble the gel into the electrophoresis system and add the running buffer to the upper and lower 


\subsection{Verification of Plastoglobule Purity by Immunoblotting}

chambers. Carefully remove the comb and wash the wells by expelling running buffer into the wells with a micropipette.

5. Load different volumes of each sample in the wells: $20 \mu \mathrm{L}$ for fractions $1-18$, and $15 \mu \mathrm{L}$ for the remaining samples. One well is loaded with $5 \mu \mathrm{L}$ of the molecular weight marker.

6. Complete the assembly of the electrophoresis system and connect to a power supply. The gel can be run at $15 \mathrm{~mA}$ until the front migration penetrates the running gel, and then at $30 \mathrm{~mA}$ until the blue dye front reaches the edge of the glass plates (around $45 \mathrm{~min}$ ).

1. Open a blotting transfer cassette in a tray filled with transfer buffer. Cut two pieces of 3MM paper and a sheet of nitrocellulose membrane at the dimensions of the cassette. Soak the $3 \mathrm{MM}$ papers, the nitrocellulose, and two sponges with transfer buffer.

2. Disassemble the SDS-PAGE electrophoresis system and remove the stacking part of the gel. Cut a small piece of the running gel at one corner to allow future orientation of the gel. Soak the running gel in transfer buffer for 2-3 s.

3. Assemble the blotting "sandwich" in the cassette with soaked elements as follows. On the cathode side, avoiding any air bubble imprisonment, lay out the following: a sponge, a sheet of $3 \mathrm{MM}$ paper, the running gel, the nitrocellulose membrane, a sheet of $3 \mathrm{MM}$ paper, and a sponge (see Note 37 ).

4. Close the cassette and introduce it into the transfer tank. It is crucial to pay attention to the orientation of the cassette in the tank with the gel on the cathode side and the membrane on the anode side. Fill the tank with transfer buffer. A magnetic stir bar is added in the tank and the tank is placed on top of a magnetic stirrer to ensure constant homogenization of the buffer. Transfer is performed at $4^{\circ} \mathrm{C}$ for $2 \mathrm{~h}$ at $250 \mathrm{~mA}$ (see Note 38).

5. Disassemble the sandwich and stain the nitrocellulose membrane in a bath of AmidoBlack staining solution for approximately $10 \mathrm{~min}$. Destain the membrane by three successive washes with destaining solution until a good contrast is obtained.

6. Rinse the membrane with deionized water and take a picture of it with a scanner or a camera. Mark the position of the standards with a pen.

7. To remove any trace of destaining solution, wash the membrane three times for 2 min each time on a rocking platform with PBS or TBS buffer, depending on the buffer to be used for the following steps. 
8. Incubate the membrane in $20 \mathrm{~mL}$ of blocking buffer for $1 \mathrm{~h}$ at room temperature on a rocking platform.

9. Incubate the membrane with the desired primary antibody at an adequate dilution for $2 \mathrm{~h}$ at room temperature or overnight at $4^{\circ} \mathrm{C}$ on a rocking platform.

10. Remove the primary antibody solution and wash the membrane three times for $10 \mathrm{~min}$ with PBS or TBS (see Note 39).

11. Incubate the membrane with secondary antibody solution for $30 \mathrm{~min}$ at room temperature on a rocking platform.

12. Wash the membrane in PBS or TBS three times for $10 \mathrm{~min}$ each time on a rocking platform.

13. In a square Petri dish, mix $2 \mathrm{~mL}$ of ECL reagent and $6.6 \mu \mathrm{L}$ of $3 \% \mathrm{H}_{2} \mathrm{O}_{2}$ (see Note 40 ). Remove excess liquid from the membrane using absorbing paper and place it into the Petri dish. Incubate the membrane for 2 min with the ECL solution making sure the membrane is uniformly covered with the solution. Remove excess ECL solution from the membrane using absorbing paper and place it into an X-ray film cassette. Cover the membrane with a clear plastic material such as wrapping film, and, once in a dark room, place a film on it. Expose the film for $30 \mathrm{~s}$ to $10 \mathrm{~min}$. The X-ray film is developed in the dark room with a tabletop processor or by successive baths in standard developer and fixative solutions. Alternatively, the luminescent signal could be monitored using a luminescence imaging device. An example of the results that are obtained is given Fig. 3.

14. It may be necessary to remove the previous antibody before hybridizing a new one. For this, incubate the membrane $30 \mathrm{~min}$ in stripping buffer and then wash it with three successive baths of PBS or TBS for 10 min each. After stripping, the membrane must be blocked and the protocol restarts at step 8 of Subheading 3.4.

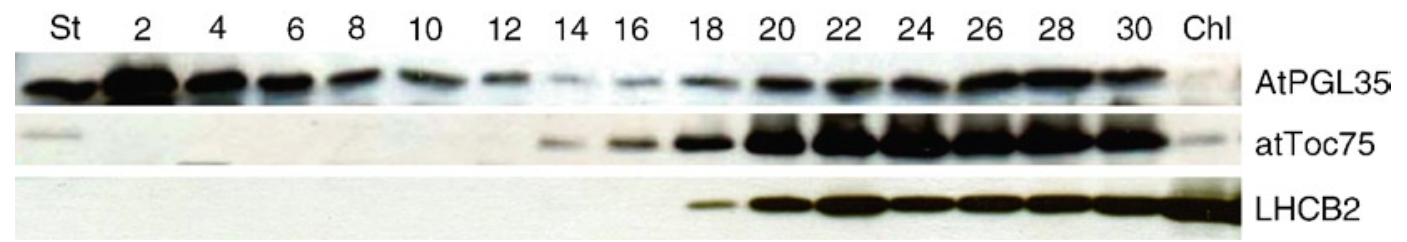

Fig. 3. Immunoblot analysis of chloroplast membrane fractions isolated from 6-week-old plants. Chloroplast membranes were separated by ultracentrifugation on a sucrose gradient. Fractions of $1 \mathrm{~mL}$ were collected from the top (fraction 1 in $5 \%$ sucrose) to the bottom (fraction 30 in $45 \%$ sucrose) of the sucrose gradient. Proteins from $400 \mu \mathrm{L}$ aliquots of the even fractions $2-18$, from $200 \mu \mathrm{L}$ aliquots of the even fractions $20-24$, from $100 \mu \mathrm{L}$ aliquots of fractions 26,28 and stroma (St), and from $50 \mu \mathrm{L}$ aliquots of fraction 30 and total chloroplasts (Chl) were precipitated, separated by SDSPAGE, and transferred to a nitrocellulose membrane. The membrane was sequentially probed with antibodies raised against membrane marker proteins: AtPGL35 (plastoglobule protein), atToc75 (outer envelope membrane protein), and LHCB2 (thylakoid protein). 
1. EDTA is not soluble below $\mathrm{pH} 8$; thus, $\mathrm{NaOH}$ should be added when preparing EDTA solution to help dissolution and after to reach the desired $\mathrm{pH}$.

2. HB buffer is an isotonic solution which will prevent osmotic shock and thus preserve intact chloroplasts. It is prepared with the following stock solutions that are autoclaved and can be stored for several months at room temperature: $1 \mathrm{M}$ Tricine$\mathrm{KOH}, \mathrm{pH}$ 8.4; 0.5 M EDTA, pH 8.5; $0.5 \mathrm{M} \mathrm{NaHCO}_{3}$; and $1 \mathrm{M} \mathrm{MnCl}_{2}$.

3. PMSF is a protease inhibitor. It is insoluble in water and must be dissolved at $0.2 \mathrm{M}$ in a solvent such as isopropanol. It is toxic: wear adequate protective clothes when handling the stock solution.

4. HB buffer can be prepared the day before and stored at $4^{\circ} \mathrm{C}$. However, sodium ascorbate, BSA, and PMSF should be added just before use.

5. RB buffer is prepared with the following stock solutions that are autoclaved and can be stored several months at room temperature: l M Tricine-KOH, pH 7.6; 0.5 M EDTA, pH 8.5; and $1 \mathrm{M} \mathrm{MgCl}_{2}$.

6. Since acetone is highly volatile, the concentration of acetone in the bottle will decrease with time and the extraction of chlorophyll will then be less efficient. Prepare new $80 \%$ acetone solution periodically.

7. TrE buffer can be prepared with the following stock solutions: $\mathrm{l} \mathrm{M}$ Tricine- $\mathrm{KOH}, \mathrm{pH} 7.5$; $0.5 \mathrm{M}$ EDTA, $\mathrm{pH} 8$; and $\mathrm{l} \mathrm{M}$ DTT (stored at $-20^{\circ} \mathrm{C}$ ).

8. APS is unstable at $4^{\circ} \mathrm{C}$. Thus, after $2-3$ days at $4^{\circ} \mathrm{C}$ a new aliquot of APS should be opened.

9. AmidoBlack solution must be stored at room temperature in a bottle surrounded by aluminium paper to avoid light damages. It can be reused several times until loss of efficiency but it is recommended to filter it from time to time.

10. ECL solution is prepared in an opaque bottle to prevent light damage, and it may be conserved at $4^{\circ} \mathrm{C}$ for several weeks. $50 \mathrm{~mL}$ of this solution should be prepared by mixing $50 \mathrm{~mL}$ of water with the following stock aliquots stored at $-20^{\circ} \mathrm{C}$ : $110 \mu \mathrm{L}$ of $90 \mathrm{mM}$ coumaric acid and $250 \mu \mathrm{L}$ of $250 \mathrm{mM}$ luminol.

11. $\beta$-Mercaptoethanol is toxic. Work under a fume hood and wear adequate protective clothes. 
12. In order to ensure homogeneous density, seeds are mixed with water in a saltshaker and then distributed on soil. Plant density is critical: high density is needed to obtain enough starting material; however, too high density will induce early flowering plants with very small leaves. For each $30 \times 50 \mathrm{~cm}$ tray, an amount of Arabidopsis seeds corresponding to a volume of approximately $20 \mu \mathrm{L}$ is used.

13. Starch accumulates as heavy granules in chloroplasts which might break the organelles during centrifugation. Therefore, it is critical to avoid starch formation before starting chloroplast preparation.

14. Leaves collected from six trays should weigh $150-300 \mathrm{~g}$.

15. Plants are immersed in chilled water to allow decantation of the soil that might have been collected with leaves.

16. Leaves are wrung to eliminate most of the tap water and then introduced into the homogenizer. Enough HB buffer is added to the leaves to allow good grinding. The total leaf amount is generally too important to be introduced all at the same time into the homogenizer; thus, only half or a third of the leaf volume is ground at a time. While the first-round homogenate is filtering, the next batch of leaves is ground with new $\mathrm{HB}$ buffer.

17. Resuspension of the pellet should be done as carefully as possible so as not to break the chloroplasts. Gently shake bottles on ice and use plastic Pasteur pipettes with large openings to transfer the solution into a new tube. The complete resuspension of the whole pellet is frequently not achieved with the first $1-2 \mathrm{~mL}$ of RB buffer. In such cases, add a supplemental $1-2 \mathrm{~mL}$ of $\mathrm{RB}$ buffer onto the remaining pellet and carefully scrape the pellet with a plastic Pasteur pipette to help its resuspension. Nevertheless, pay attention not to resuspend the pellet in an excessive total volume of RB, to allow loading the Percoll gradients with no more than $3 \mathrm{~mL}$ of crude extract. If necessary, prepare extra Percoll gradients.

18. Disconnect the break so as not to disturb the gradient during deceleration.

19. Chlorophyll content is measured by diluting $5 \mu \mathrm{l}$ of resuspended chloroplasts in $1 \mathrm{~mL}$ of $80 \%$ acetone. Mix well by vortexing and spin for $2 \mathrm{~min}$ at maximum speed in a microcentrifuge. Transfer the supernatant into a quartz cuvette (a plastic cuvette can be used if the plastic is resistant to acetone) and measure the absorbance at $652 \mathrm{~nm}\left(\mathrm{~A}_{652}\right)$ against a blank of $80 \%$ acetone. Chlorophyll concentration is calculated as follows:

[Chlorophyll $](\mathrm{mg} / \mathrm{mL})=A_{652} \times$ dilution factor $/ 36$ 
20. The pellet can be resuspended by vortexing, since at this step the integrity of chloroplasts need not be preserved.

21. The freezing and thawing cycle participates in the disruption of the chloroplasts.

22. Defrosting and mechanical grinding using a Potter homogenizer breaks the chloroplasts.

23. Dilution of the chloroplast suspension followed by ultracentrifugation at $100,000 \times g$ allows the separation of stroma from other chloroplast components (i.e., total chloroplast membranes, including plastoglobules). For protein analysis, an aliquot of the stroma fraction is taken from the supernatant and stored at $-80^{\circ} \mathrm{C}$.

24 . The volume of $45 \%$ sucrose solution to be used for membrane resuspension is determined to (1) reach $2-6 \mathrm{mg} / \mathrm{mL}$ of chlorophyll concentration and (2) allow the loading of 2-4 gradients ( $5 \mathrm{~mL}$ on each gradient). With this concentration, each gradient will be loaded with $10-30 \mathrm{mg}$ of total membranes, which is the optimal chlorophyll amount needed for efficient plastoglobule preparation with a gradient of $30 \mathrm{~mL}$.

25. At this step, the membrane solution can be stored at $-80^{\circ} \mathrm{C}$ for later fractionation.

26. Efficient homogenization with 20 strokes of the Potter homogenizer is critical to detach plastoglobules from the thylakoid membranes. Possibly, the chloroplast suspension can be sonicated for 1-2 min to help dissociation of plastoglobules from the thylakoids.

27. Use plastic Pasteur pipettes to gently load each sucrose solution on top of the preceding phase, taking care not to disturb the gradient.

28. This ultracentrifugation allows the separation of the different plastid membranes (envelopes, thylakoids and plastoglobules) by flotation in the discontinuous sucrose gradient.

29. Disconnect the break so as not to disturb the gradient during deceleration.

30. The precipitated volume of the first fractions $(1-18)$ is doubled because of the low protein abundance in these fractions.

31. The proteins are present at the interface as a white band. However, in the first fractions, this white band is not visible due to low protein abundance. This does not prejudge the success of the experiment.

32. The protein pellet can also be dried by leaving tubes open under a chemical hood for $1 \mathrm{~h}$ to overnight. 
33. The abundance of proteins in the last fractions makes it difficult to resuspend the pellet. This is why a higher volume of SB is added to these fractions.

34. Nonpolymerized acrylamide is toxic; therefore, wear appropriated protective clothes.

35. APS and TEMED catalyze the gel polymerization. High temperature results in faster polymerization. It may be useful to pour the gel in a cold room during summer time.

36. The space needed for the stacking gel is approximately $1 \mathrm{~cm}$ below the comb.

37. To remove any air bubbles which may have formed between the different layers of the sandwich and which will interfere with the blotting process, use a plastic spatula and gently roll air bubbles out.

38. Alternatively, transfer could be done overnight at $100 \mathrm{~mA}$, in the cold room.

39. Primary antibody solution can be kept at $-20^{\circ} \mathrm{C}$ and reused three to five times depending on the antibody.

40. Once $\mathrm{H}_{2} \mathrm{O}_{2}$ is added to the ECL reagent, the stability of the solution is approximately $15 \mathrm{~min}$. Thus, the following steps need to be rapidly performed.

\section{Acknowledgments}

We would like to thank Dr. S. Melser and Dr. C. Garcion for critical reading of the manuscript.

\section{References}

1. Bréhélin, C., and Kessler, F. (2008) The plastoglobule: a bag full of lipid biochemistry tricks. Photochem. Photobiol. 84, 1388-1394.

2. Austin, J. R., Frost, E., Vidi, P. A., Kessler, F., and Staehelin, L. A. (2006) Plastoglobules are lipoprotein subcompartments of the chloroplast that are permanently coupled to thylakoid membranes and contain biosynthetic enzymes. Plant Cell 18, 1693-1703.

3. Vidi, P. A., Kanwischer, M., Baginsky, S., Austin, J. R., Csucs, G., Dörmann, P., Kessler, F., and Bréhélin, C. (2006) Tocopherol Cyclase (VTEl) Localization and vitamin $\mathrm{E}$ Accumulation in chloroplast plastoglobule lipoprotein particles. J. Biol. Chem. 281, 11225-11234.

4. Ytterberg, A. J., Peltier, J. B., and van Wijk, K. J. (2006) Protein profiling of plastoglobules in chloroplasts and chromoplasts. A surprising site for differential accumulation of metabolic enzymes. Plant Physiol. 140, 984-997.

5. Lohmann, A., Schottler, M. A., Bréhélin, C., Kessler, F., Bock, R., Cahoon, E. B., and Dörmann, P. (2006) Deficiency in phylloquinone (vitamin $K(1)$ ) methylation affects prenyl quinone distribution, photosystem I abundance, and anthocyanin accumulation in the 
Arabidopsis AtmenG mutant. J. Biol. Chem. 281, 40461-40472.

6. Zbierzak, A. M., Kanwischer, M., Wille, C., Vidi, P. A., Giavalisco, P., Lohmann, A., Briesen, I., Porfirova, S., Brehelin, C., Kessler, F., and Dörmann, P. (2009) Intersection of the tocopherol and plastoquinol metabolic pathways at the plastoglobule. Biochem. J. 425, 389-399.

7. Gaude, N., Bréhélin, C., Tischendorf, G., Kessler, F., and Dörmann, P. (2007) Nitrogen deficiency in Arabidopsis affects galactolipid composition and gene expression and results in accumulation of fatty acid phytyl esters. Plant J. 49, 729-739.

8. Kessler, F., Schnell, D., and Blobel, G. (1999) Identification of proteins associated with plastoglobules isolated from pea (Pisum sativum L.) chloroplasts. Planta 208, 107-113.

9. Vidi, P. A., Kessler, F., and Bréhélin, C. (2007) Plastoglobules: a new address for targeting recombinant proteins in the chloroplast. $B M C$ Biotechnol. 7, 4 . 